\title{
A long-term monthly assessment of land surface temperature and normalized difference vegetation index using Landsat data
}

\author{
Uma avaliação mensal de longo prazo da temperatura da \\ superfície da terra e índice de vegetação de diferença \\ normalizada usando dados Landsat
}

Subhanil Guha[a] [D]

[a] National Institute of Technology Raipur, Department of Applied Geology, Raipur, India

How to cite: Guha, S. (2021). A long-term monthly assessment of land surface temperature and normalized difference vegetation index using Landsat data. urbe. Revista Brasileira de Gestão Urbana, v.13, e20200345. https://doi.org/10.1590/2175-

3369.013.e20200345

\section{Abstract}

The present study assesses the monthly variation of land surface temperature (LST) and the relationship between LST and normalized difference vegetation index (NDVI) in Raipur City of India using one hundred and eighteen Landsat images from 1988 to 2019. The results show that a monthly variation is observed in the mean LST. The highest mean LST is found in April $\left(38.79^{\circ} \mathrm{C}\right)$, followed by May $\left(36.64^{\circ} \mathrm{C}\right)$, June $\left(34.56^{\circ} \mathrm{C}\right)$, and $\operatorname{March}\left(32.11^{\circ} \mathrm{C}\right)$. The lowest mean LST is observed in January $\left(23.01^{\circ} \mathrm{C}\right)$, followed by December $\left(23.76^{\circ} \mathrm{C}\right)$, and November $\left(25.83^{\circ} \mathrm{C}\right)$. A moderate range of mean LST is noticed in September $\left(27.18^{\circ} \mathrm{C}\right)$, October $\left(27.22^{\circ} \mathrm{C}\right)$, and February $\left(27.88^{\circ} \mathrm{C}\right)$. Pearson's linear correlation method is used to correlate LST with NDVI. The LST-NDVI correlation is strong negative in October (-0.62), September (-0.55), and April (-0.51). The moderate negative correlation is developed in March (-0.40), May (-0.44), June (-0.47), and November (-0.39). A weak negative correlation is observed in December (-0.21), January (-0.24), and February $(-0.29)$. The change in weather elements and variation in land surface characteristics contribute to the monthly fluctuation of mean LST and LST-NDVI correlation. The study will be an effective one for the town and country planners for their future estimation of land conversion.

Keywords: Landsat. Land surface. Land surface temperature. Normalized difference vegetation index. Raipur. 


\section{Resumo}

o presente estudo avalia a variação mensal da temperatura da superfície terrestre (LST) e a relação entre IST e o índice de vegetação de diferença normalizado (NDVI) na cidade de Raipur, na Índia, utilizando cento e dezoito imagens landsat de 1988 a 2019. Os resultados mostram que uma variação mensal é observada no LST médio. O LST médio mais elevado é encontrado em abril (38,79oC), seguido por maio (36.64oC), junho (34.56oC) e março (32.11oC). O LST médio mais baixo é observado em janeiro (23.01oC), seguido por dezembro (23.76oC) e novembro $(25,83 o C)$. Uma gama moderada de LST médio é notada em setembro (27.18oC), outubro (27.22oC) e fevereiro (27.88oC). $O$ método linear de correlação de Pearson é usado para correlacionar LST com NDVI. A correlação LST-NDVI é fortemente negativa em outubro $(-0,62)$, setembro $(-0,55)$ e abril $(-0,51)$. A correlação negativa moderada é desenvolvida em março $(-0,40)$, maio $(-0,44)$, junho $(-0,47)$ e novembro $(-0,39)$. Uma correlação negativa fraca é observada em dezembro $(-0,21)$, janeiro $(-0,24)$ e fevereiro $(-0,29)$. A alteração dos elementos meteorológicos e a variação das características da superfície terrestre contribuem para a flutuação mensal da correlação média LST e LST-NDVI. O estudo será eficaz para os planeadores da cidade e do país para a sua futura estimativa da conversão de terras.

Palavras-chave: Landsat. Superfície de terra. Temperatura da superfície do terreno. Índice de vegetação de diferença normalizado. O Raipur.

\section{Introduction}

The thermal infrared (TIR) region of the electromagnetic spectrum has a huge potential in determining the nature and characteristics of land surface dynamics in any natural environment along with the visible and nearinfrared (VNIR) and shortwave infrared (SWIR) regions (Chen et al., 2006; Ghobadi et al., 2014; Guha et al., 2018; Guha \& Govil, 2020; Guha \& Govil, 2021a; Guha \& Govil, 2019; Alexander, 2020). Land surface temperature (LST) is a major factor to assess the biogeochemical actions in the formation of land surface materials and it is the most essential parameter to evaluate the ecological condition of rural or urban areas (Tomlinson et al., 2011; Hao et al., 2016). LST varies with the changes of tone, texture, pattern, and association of the land surface types in any region (Hou et al., 2010). Generally, green vegetation and water bodies present low LST, whereas a built-up area, bare rock surface, or dry soil reflects high LST (Guha et al., 2019). Thus, LSTrelated studies are very important in urban and land use planning and development (Li et al., 2017; Guha, Govil \& Besoya, 2020; Guha, Govil, Gill \& Dey, 2020a). Urban heat islands and urban hot spots are very common term in an urban environment and are indicated by the zone of very high LST inside the urban bodies (Guha et al., 2017). The most popular spectral index is the normalized difference vegetation index (NDVI) which is used in extracting green vegetation (Yuan et al., 2017; Guha \& Govil, 2021b; Mondal et al., 2011; Guha, 2016; Guha, Govil, Gill \& Dey, 2020b; Guha, Govil, Dey et al., 2020; Guha, Govil, Gill \& Dey, 2020c; Guha, Govil \& Diwan, 2020). NDVI is directly used in the determination of land surface emissivity and thus is a significant factor for LST estimation (Sobrino et al., 2004; Carlson \& Ripley, 1997).

Currently, the relationship between LST and NDVI was constructed using thermal infrared remote sensing technology and only some satellite sensors have the thermal bands like Landsat, MODIS, and ASTER (Wen et al., 2017; Guha et al., 2017). The required wavelength of these thermal bands is 8-14 $\mu \mathrm{m}$ for LST determination. An infrared thermometer instrument is used to validate the derived LST values (Li et al., 2017; Guha, Govil \& Besoya, 2020; Guha, Govil, Gill \& Dey, 2020a; Guha et al., 2017). LST-NDVI relationship was applied in most of the thermal remote sensing studies that were conducted with temporal discrete data sets on the urban environment, e.g., Tokyo, Melbourne, Shiraz, Raipur (Shigeto, 1994; Jamei et al., 2019; Fatemi \& Narangifard, 2019; Guha \& Govil, 2021c). Ferelli et al. (2018) correlate LST with NDVI in Monte Hermosoof Argentina. Fewer studies are available on the long-term and continuous seasonal correlation among LST, NDVI, and LULC in a tropical city. 
A reverse relationship is built between LST and the concentration of green vegetation and thus, NDVIis used as an important factor for determining LST in most of the LST retrieval methods (Voogt \& Oke, 2003; Gutman \& Ignatov, 1998; Goward et al., 2002; Govil et al., 2019; Guha, 2021; Govil et al., 2020).

There are so many valuable research articles found on LST-NDVI relationships that were conducted mainly in the Chinese landscape (Gui et al., 2019; Qu et al., 2020; Qu et al., 2018; Cui, Wang, Qu, Singh, Lai, Jiang\& Yao, 2019; Cui, Wang, Qu, Singh, Lai\& Yao, 2019; Yao, Cao et al., 2019; Yao, Wang, Gui et al., 2017; Yao, Wang, Huang, Chen et al., 2018; Yao, Wang et al., 2019; Yao, Wang, Huang et al., 2017; Yao, Wang, Huang, Zhang et al., 2018; Yuan et al., 2020). Some recent studies successfully analyze the LST-NDVI correlation in some tropical Indian cities (Kikon et al., 2016; Kumar \& Shekhar, 2015; Mathew et al., 2018; Mathew et al., 2017; Sannigrahi et al., 2018; Singh et al., 2017). The nature of LST and NDVI varies due to the seasonal change of evaporation, precipitation, moisture content, air temperature, etc. But, time-series analysis of the monthly variation in the LST-NDVI relationship in a tropical Indian city is rare.

It is a necessary task to build a month-wise LST-NDVI correlation for the sustainable development of town and country planning. Thus, to determine the characteristic features of monthly variation of LST-NDVI correlation, Raipur City of India was selected as it is not under any kind of extreme climatic condition and it is a smart city with a rapid land conversion. Generally, the LST-NDVI correlation is negative on the tropical cities of similar environmental conditions of Raipur. But, the strength of the LST-NDVI relationship can change temporally, seasonally, and spatially. The relationship is changed with time as the land surface materials change with time. Elevation and slope are two main physiographic influencing factors that generate a negative correlation with LST. Wind speed and humidity are two climatic factors that create a negative relationship with LST. The relationship also depends on the LULC types as vegetation, soil, water, or built-up area change the values of NDVI as well as LST. Different seasons also play a significant role in the LST-NDVI relationship as the growth of vegetation and increase of LST primarily depend on seasonal change. But, no specific conclusion can draw between LST and NDVI by using a small number of remotely sensed data or within a short duration of research. A strong conclusion on the LST-NDVI relationship can be drawn only after the analyses of the multitemporal and multi-seasonal data sets for a long-term continuous timeframe. Thus, large Landsat data sets are necessary to obtain a reliable result on this relationship. The present study analyzes the nature, strength, and trend of the effect of LST on NDVI and the LST-NDVI correlation on different types of LULC and their seasonal variation from 1988 to 2019. Thus, the new direction of the study is the long-term monthly change of LST-NDVI correlation analysis using the time-series data of Landsat sensors. The objective of the current research is to analyze the response of mean LST and LST-NDVI correlation in different months.

\section{Study area and data}

Figure 1 shows the research place (Raipur City of India) of the present research work. Figure 1(a) presents the outline map of India where Chhattisgarh State is located in the middle part (Source: Survey of India). Figure 1(b) presents the outline map of Chhattisgarh State with districts (Source: Survey of India). Figure 1(c) represents the false colour composite (FCC) image of Raipur City from recent Landsat 8 data (Date: 7 November 2018) where blue, green, and red bands of the image are filtered by the green, red, and infrared bands, respectively. False colour composite images are the combination of bands other than visible red, green, and blue as the red, green, and blue components of the display. These images are useful to allow us to distinguish various types of land surface materials that are difficult to identify by the naked eye or true colour composite image. Figure 1(d) indicates the contour map (Date: 11 October 2011) of the city from Advanced Spaceborne Thermal Emission and Reflection Radiometer (ASTER) Digital Elevation Model (DEM) data (Source: USGS). The city extends from $21^{\circ} 11^{\prime} 22^{\prime \prime} \mathrm{N}$ to $21^{\circ} 20^{\prime} 02^{\prime \prime} \mathrm{N}$ and from $81^{\circ} 32^{\prime} 20^{\prime \prime} \mathrm{E}$ to $81^{\circ} 41^{\prime} 50^{\prime \prime E}$. The total area of the city is approximately $164.23 \mathrm{~km}^{2}$. The only big river in the area is Mahanadi. The south of the city is covered by dense forests. Geologically the city is very stable and no such major geological hazards are seen in the area. The central urbe. Revista Brasileira de Gestão Urbana, 2021, 13, e20200345 
part of the city has a higher elevation compared to the periphery area. According to India Meteorological Department (IMD), Raipur is under the savannah type of climate. Table 1 presents the climatic data of Raipur from 1981-2012 (Source: IMD). May is the hottest month followed by April, June, and March. July is the rainiest month followed by August, June, and September. October and November are the post-monsoon months that experience pleasant weather conditions. December (the coldest month), January, and February are the winter months. The pre-monsoon and winter months (including November) remain dry compared to the monsoon and post-monsoon months.

Table 1 -Climate data for Raipur City (1981-2012)

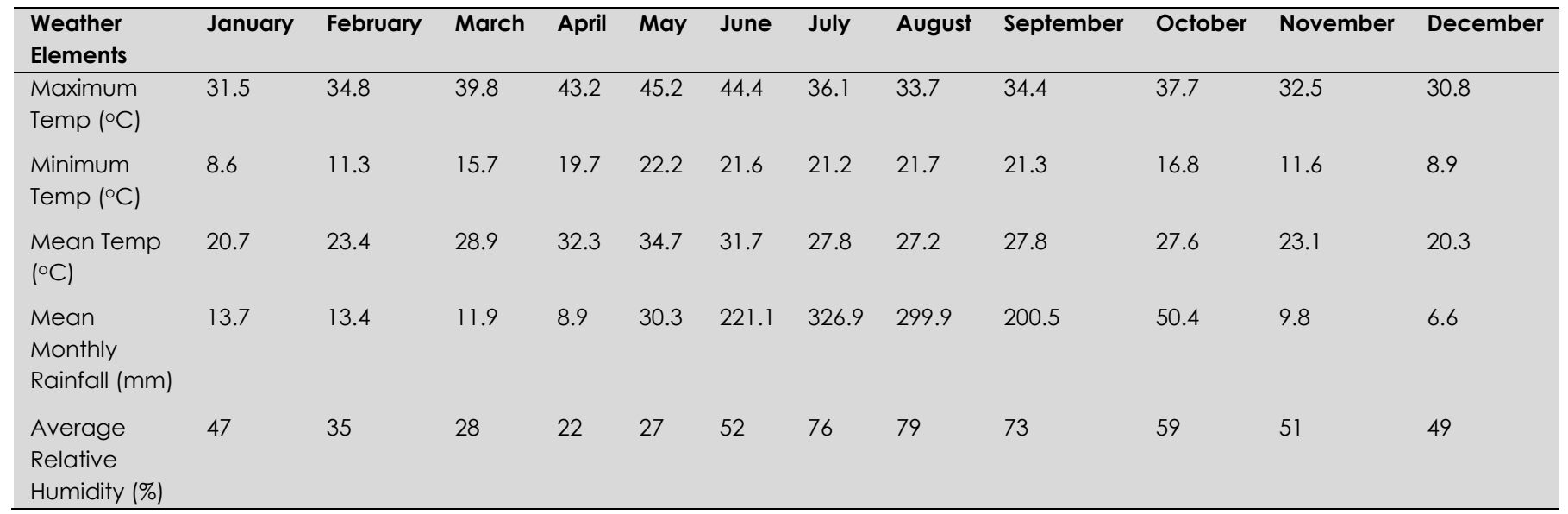

Source: IMD (2020).

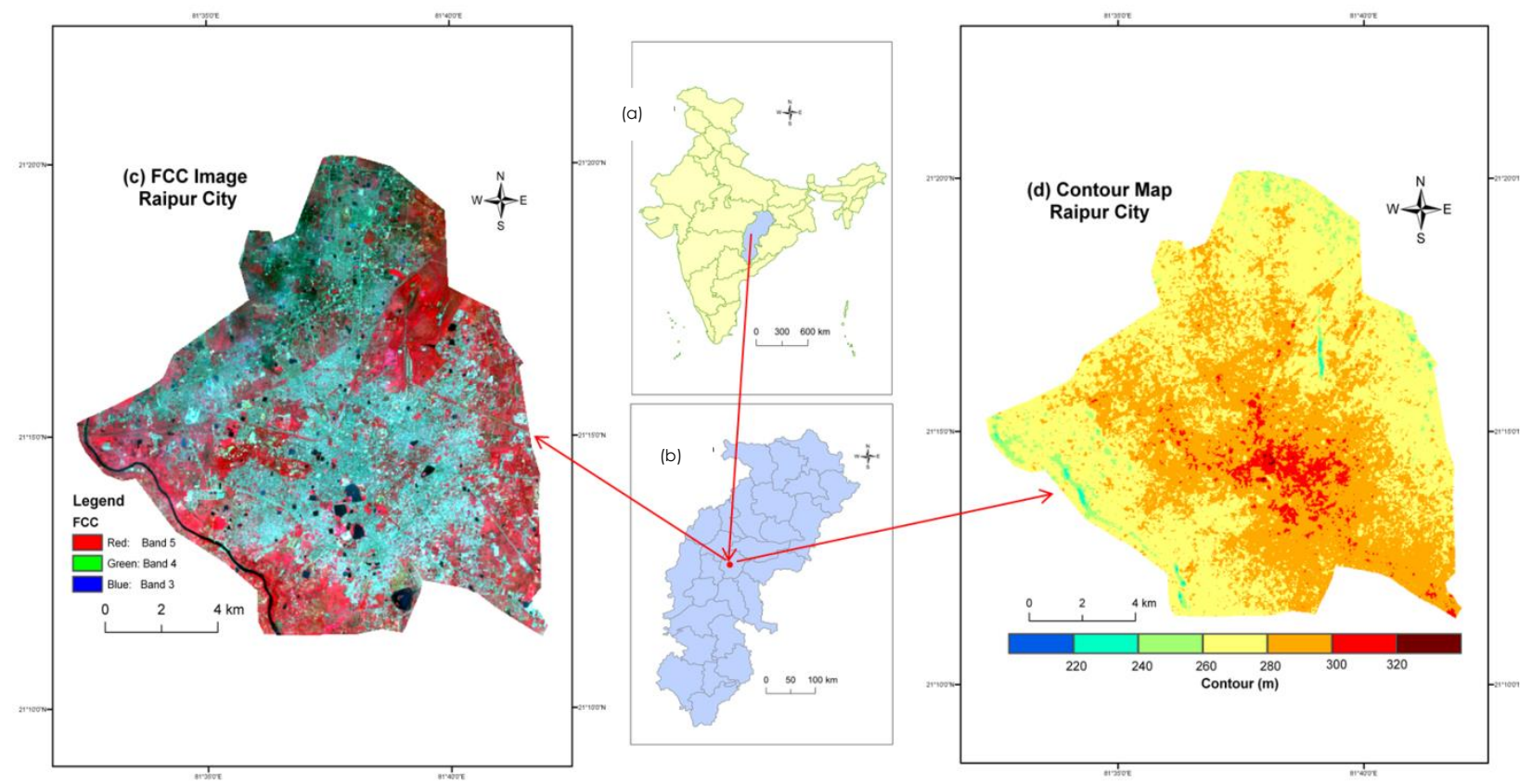

Figure 1 - Location of the study area (a) India (b) Chhattisgarh (c) FCC image of Raipur (d) Contour Map of Raipur showing the contours of 220 m, 240 m, 260 m, 280 m, 300 m, and 320 m. Source: Authors (2020).

Table 2 shows the resolution and wavelength information visible to near-infrared (VNIR) bands, shortwave infrared (SWIR) bands, and thermal infrared (TIR) bands of different types of Landsat satellite sensors. 
A long-term monthly assessment of land surface temperature and normalized difference vegetation index using Landsat data

Table 2 - Band and wavelength information about various types of Landsat sensors

\begin{tabular}{|c|c|c|c|c|c|c|c|c|}
\hline \multicolumn{3}{|c|}{ Landsat $5 \mathrm{TM}$} & \multicolumn{3}{|c|}{ Landsat 7 ETM+ } & \multicolumn{3}{|c|}{ Landsat 8 OLI/TIRS } \\
\hline Bands & $\begin{array}{l}\text { Wavelength } \\
(\mu \mathrm{m})\end{array}$ & $\begin{array}{l}\text { Resolution } \\
\text { (m) }\end{array}$ & Bands & $\begin{array}{l}\text { Wavelength } \\
(\mu \mathrm{m})\end{array}$ & $\begin{array}{l}\text { Resolution } \\
\text { (m) }\end{array}$ & Bands & $\begin{array}{l}\text { Wavelength } \\
(\mu \mathrm{m})\end{array}$ & $\begin{array}{l}\text { Resolution } \\
\text { (m) }\end{array}$ \\
\hline $\begin{array}{l}\text { Band 1- } \\
\text { Blue }\end{array}$ & $0.45-0.52$ & 30 & $\begin{array}{l}\text { Band } 1- \\
\text { Blue }\end{array}$ & $0.45-0.52$ & 30 & $\begin{array}{l}\text { Band1- } \\
\text { Ultra Blue }\end{array}$ & $0.435-0.451$ & 30 \\
\hline $\begin{array}{l}\text { Band2- } \\
\text { Green }\end{array}$ & $0.52-0.60$ & 30 & $\begin{array}{l}\text { Band2- } \\
\text { Green }\end{array}$ & $0.52-0.60$ & 30 & $\begin{array}{l}\text { Band2- } \\
\text { Blue }\end{array}$ & $0.452-0.512$ & 30 \\
\hline $\begin{array}{l}\text { Band3- } \\
\text { Red }\end{array}$ & $0.63-0.69$ & 30 & $\begin{array}{l}\text { Band3- } \\
\text { Red }\end{array}$ & $0.63-0.69$ & 30 & $\begin{array}{l}\text { Band3- } \\
\text { Green }\end{array}$ & $0.533-0.590$ & 30 \\
\hline $\begin{array}{l}\text { Band4- } \\
\text { NIR }\end{array}$ & $0.76-0.90$ & 30 & $\begin{array}{l}\text { Band4- } \\
\text { NIR }\end{array}$ & $0.77-0.90$ & 30 & Band4-Red & $0.636-0.673$ & 30 \\
\hline $\begin{array}{l}\text { Band5- } \\
\text { SWIR } 1\end{array}$ & $1.55-1.75$ & 30 & $\begin{array}{l}\text { Band5- } \\
\text { SWIR1 }\end{array}$ & $1.55-1.75$ & 30 & Band5-NIR & $0.851-0.879$ & 30 \\
\hline $\begin{array}{l}\text { Band6- } \\
\text { TIR }\end{array}$ & $10.40-12.50$ & $120^{*}(30)$ & $\begin{array}{l}\text { Band6- } \\
\text { TIR }\end{array}$ & $10.40-12.50$ & $60^{* *}(30)$ & $\begin{array}{l}\text { Band6- } \\
\text { SWIR1 }\end{array}$ & $1.566-1.651$ & 30 \\
\hline \multirow[t]{5}{*}{$\begin{array}{l}\text { Band7- } \\
\text { SWIR2 }\end{array}$} & $2.08-2.35$ & 30 & $\begin{array}{l}\text { Band7- } \\
\text { SWIR2 }\end{array}$ & $2.09-2.35$ & 30 & $\begin{array}{l}\text { Band7- } \\
\text { SWIR2 }\end{array}$ & $2.107-2.294$ & 30 \\
\hline & & & $\begin{array}{l}\text { Band8- } \\
\text { Pan }\end{array}$ & $0.52-0.90$ & 15 & Band8-Pan & $0.503-0.676$ & 15 \\
\hline & & & & & & $\begin{array}{l}\text { Band9- } \\
\text { Cirrus }\end{array}$ & $1.363-1.384$ & 30 \\
\hline & & & & & & $\begin{array}{l}\text { Band10- } \\
\text { TIR I }\end{array}$ & $10.60-11.19$ & $100^{* * *}(30)$ \\
\hline & & & & & & $\begin{array}{l}\text { Band1 1- } \\
\text { TIR2 }\end{array}$ & $11.50-12.51$ & $100^{* * *}(30)$ \\
\hline
\end{tabular}

Note:"TM band 6 was acquired at $120 \mathrm{~m}$ resolution, but products are resampled by USGS to $30 \mathrm{~m}$ pixels. "ETM+ band 6 is acquired at $60 \mathrm{~m}$ resolution, but products are resampled by USGS to $30 \mathrm{~m}$ pixels." "'TIRS bands 10 and 11 are acquired at $100 \mathrm{~m}$ resolution, but products are resampled by USGS to $30 \mathrm{~m}$ pixels. Source: USGS.

One hundred and eighteen available cloud-free Landsat TM, ETM+, and OLI/TIRS data from 1988 to 2019 were freely downloaded from the USGS Data Centre (Table 2) to conduct the whole study. OLI/TIRS dataset has two TIR bands (bands 10 and 11). This large dataset was prepared by taking eleven data from January, fifteen from February, thirteen from March, ten from April, seventeen from May, four from June, four from September, thirteen from October, fifteen from November, and sixteen from December. There are very few cloud-free data sets available in the wet season (June-September), and this phenomenon could have an impact on the result of the retrieved LST. These Landsat data sets passed over the Raipur City every day between 10:00 AM to 10:30 AM. Hence, there is a scope to retrieve the LST of the study area at a specific time every day. The TIR band 10 data (100 m resolution) was applied for the current research due to better-calibrated certainty (Guha et al., 2018). The TIR band 10 data was resampled to $30 \mathrm{~m}$ x $30 \mathrm{~m}$ pixel size by the USGS data centre. TM data has only one TIR band (band 6) of $120 \mathrm{~m}$ resolution that was also resampled to $30 \mathrm{~m}$ x $30 \mathrm{~m}$ pixel size by the USGS data centre. ETM+ data has a TIR band (band 6) of $60 \mathrm{~m}$ resolution, and it was again resampled to $30 \mathrm{~m} \times 30 \mathrm{~m}$ pixel size by the USGS data centre. The spatial resolution of the VNIR bands of the three types of Landsat sensors is $30 \mathrm{~m}$. 
A long-term monthly assessment of land surface temperature and normalized difference
vegetation index using Landsat data

Table 3 - Specification of TM, ETM+, and OLI/TIRS data used in the present study

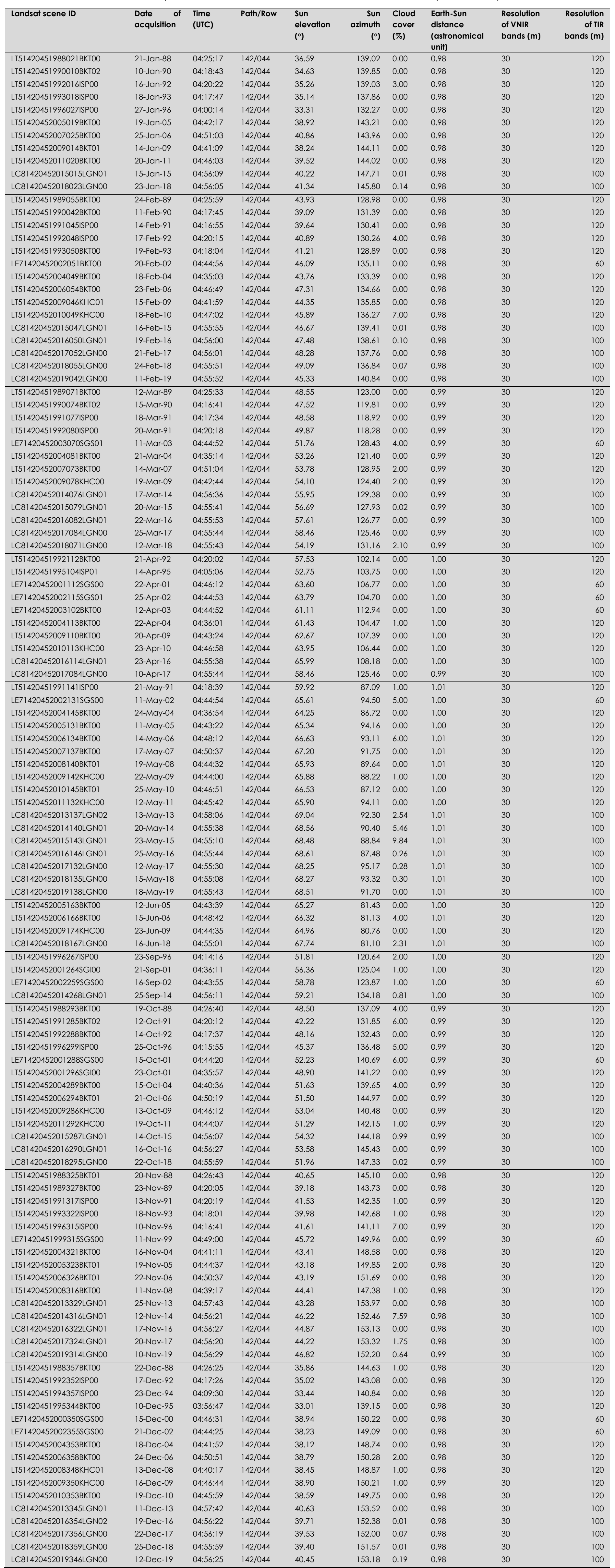




\section{Methodology}

\section{Retrieving LST from Landsat data}

In this study, the mono-window algorithm was applied to retrieve LST from multi-temporal Landsat satellite sensors where three necessary parameters are ground emissivity, atmospheric transmittance, and effective mean atmospheric temperature (Qin et al., 2001; Wang et al., 2016; Wang et al., 2019; Sekertekin \& Bonafoni, 2020). At first, the original TIR bands (100 m resolution for Landsat 8 OLI/TIRS data, $60 \mathrm{~m}$ resolution for Landsat $7 \mathrm{ETM}+$ data, and $120 \mathrm{~m}$ resolution for Landsat $5 \mathrm{TM}$ data) were resampled into $30 \mathrm{~m}$ by the USGS data centre for further application.

The TIR pixel values are firstly converted into radiance from digital number (DN) values. Radiance for TIR band of Landsat 5 TM data and Landsat 7 ETM+ data is obtained using Eq. (1) (USGS):

$$
L_{\lambda}=\left[\frac{L_{M A X \lambda}-L_{M I N \lambda}}{Q C A L_{M A X}-Q C A L_{M I N}}\right] *\left[Q_{C A L}-Q C A L_{M I N}\right]+L_{M I N \lambda}
$$

where, $L_{\lambda}$ is Top of Atmosphere (TOA) spectral radiance $\left(\mathrm{Wm}^{-2} \mathrm{sr}^{-1} \mathrm{~mm}^{-1}\right), Q_{C A L}$ is the quantized calibrated pixel value in DN, $L_{M I N \lambda}\left(\mathrm{Wm}^{-2} \mathrm{sr}^{-1} \mathrm{~mm}^{-1}\right)$ is the spectral radiance scaled to $Q C A L_{M I N}, L_{M A X \lambda}\left(\mathrm{Wm}^{-2} \mathrm{sr}^{-1} \mathrm{~mm}^{-1}\right)$ is the spectral radiance scaled to $Q C A L_{M A X}, Q C A L_{M I N}$ is the minimum quantized calibrated pixel value in $\mathrm{DN}$ and $Q C A L_{M A X}$ is the maximum quantized calibrated pixel value in DN. $L_{M I N \lambda}, L_{M A X \lambda}, Q C A L_{M I N}$, and $Q C A L_{M A X}$ values are obtained from the metadata file of Landsat TM and ETM+ data. Radiance for Landsat 8 TIR band is obtained from Eq. (2) (Zanter, 2019):

$$
L_{\lambda}=M_{L} \cdot Q_{C A L}+A_{L}
$$

where, $L_{\lambda}$ is the TOA spectral radiance $\left(\mathrm{Wm}^{-2} \mathrm{sr}^{-1} \mathrm{~mm}^{-1}\right), M_{L}$ is the band-specific multiplicative rescaling factor from the metadata, $A_{L}$ is the band-specific additive rescaling factor from the metadata, $Q_{C A L}$ is the quantized and calibrated standard product pixel values (DN). All of these variables can be retrieved from the metadata file of Landsat 8 OLI/TIRS data.

For Landsat 5 TM data and Landsat 7 ETM+ data, the reflectance value is obtained from radiances using Eq. (3) (USGS):

$$
\rho_{\lambda}=\frac{\pi \cdot L_{\lambda} \cdot d^{2}}{E S U N_{\lambda} \cdot \cos \theta_{s}}
$$

where, $\rho_{\lambda}$ is unitless planetary reflectance, $L_{\lambda}$ is the TOA spectral radiance $\left(\mathrm{Wm}^{-2} \mathrm{sr}^{-1} \mu \mathrm{m}^{-1}\right), d$ is Earth-Sun distance in astronomical units, $E S U N_{\lambda}$ is the mean solar exo-atmospheric spectral irradiances $\left(\mathrm{Wm}^{-2} \mu \mathrm{m}^{-1}\right)$ and $\theta_{s}$ is the solar zenith angle in degrees. $E S U N_{\lambda}$ values for each band of Landsat 5 can be obtained from the handbooks of the related mission. $\theta_{s}$ and $d$ values can be attained from the metadata file.

For Landsat 8 OLI/TIRS data, reflectance conversion can be applied to DN values directly as in Eq. (4) (Zanter, 2019): 


$$
\rho_{\lambda}=\frac{M_{\rho} \cdot Q_{C A L}+A_{\rho}}{\sin \theta_{S E}}
$$

where, $M_{\rho}$ is the band-specific multiplicative rescaling factor from the metadata, $A_{\rho}$ is the band-specific additive rescaling factor from the metadata, $Q_{C A L}$ is the quantized and calibrated standard product pixel values (DN) and $\theta_{S E}$ is the local sun elevation angle from the metadata file.

Eq. (5) is used to convert the spectral radiance to at-sensor brightness temperature (Wukelic et al., 1989).

$$
T_{b}=\frac{K_{2}}{\ln \left(\frac{K_{1}}{L_{\lambda}}+1\right)}
$$

where, $T_{b}$ is the brightness temperature in Kelvin $(\mathrm{K}), L_{\lambda}$ is the spectral radiance in $\mathrm{Wm}^{-2} \mathrm{sr}^{-1} \mathrm{~mm}^{-1} ; K_{2}$ and $K_{1}$ are calibration constants. For Landsat 8 data, $K_{1}$ is $774.89, K_{2}$ is $1321.08\left(\mathrm{Wm}^{-2} \mathrm{sr}^{-1} \mathrm{~mm}^{-1}\right)$. For Landsat 7 data, $K_{1}=666.09, K_{2}=1282.71\left(\mathrm{Wm}^{-2} \mathrm{sr}^{-1} \mathrm{~mm}^{-1}\right)$. For Landsat 5 data, $K_{1}$ is $607.76, K_{2}$ is $1260.56\left(\mathrm{Wm}^{-2} \mathrm{sr}^{-1} \mathrm{~mm}^{-1}\right)$.

The land surface emissivity $\varepsilon$, is estimated using the NDVI Thresholds Method (Sobrino et al., 2004). The fractional vegetation $F_{v}$, of each pixel, is determined from the NDVI using the following equation (Carlson \& Ripley, 1997):

$$
F_{v}=\left(\frac{N D V I-N D V \mathrm{I}_{\mathrm{min}}}{N D V \mathrm{I}_{\mathrm{m} a x}-N D V \mathrm{I}_{\mathrm{min}}}\right)^{2}
$$

where, $N D V \mathrm{I}_{\text {min }}$ is the minimum NDVI value (0.2) for bare soil pixel and $N D V \mathrm{I}_{\text {max }}$ is the maximum NDVI value $(0.5)$ for healthy vegetation pixel.

$d \varepsilon$ is the effect of the geometrical distribution of the natural surfaces and internal reflections. For mixed and elevated land surfaces, the value of $d \varepsilon$ may be $2 \%$ (Sobrino et al., 2004).

$$
d \varepsilon=\left(1-\varepsilon_{s}\right)\left(1-F_{v}\right) F \varepsilon_{v}
$$

where, $\varepsilon_{v}$ is vegetation emissivity, $\varepsilon_{s}$ is soil emissivity, $F_{v}$ is fractional vegetation, $F$ is a shape factor whose mean is 0.55 (Sobrino et al., 2004).

$$
\varepsilon=\varepsilon_{v} F_{v}+\varepsilon_{s}\left(1-F_{v}\right)+d \varepsilon
$$

where, $\varepsilon$ is the land surface emissivity that is determined by the following equation (Sobrino et al., 2004):

$$
\varepsilon=0.004 * F_{v}+0.986
$$

Water vapour content is estimated by the following equation (Li, 2006; Yang \& Qiu, 1996):

$$
w=0.0981 *\left[10 * 0.6108 * \exp \left(\frac{17.27 *\left(T_{0}-273.15\right)}{237.3+\left(T_{0}-273.15\right)}\right) * R H\right]+0.1697
$$


where, $w$ is the water vapour content $\left(\mathrm{g} / \mathrm{cm}^{2}\right), T_{0}$ is the near-surface air temperature in Kelvin $(\mathrm{K}), R H$ is the relative humidity (\%). These parameters of the atmospheric profile are obtained from the Meteorological Centre, Raipur (http://www.imdraipur.gov.in). Atmospheric transmittance is determined for Raipur City using the following equation (Qin et al., 2001; Sun et al., 2010):

$$
\tau=1.031412-0.11536 w
$$

where, $\tau$ is the total atmospheric transmittance, $\varepsilon$ is the land surface emissivity.

Raipur City is located in the tropical region. Thus, the following equations are applied to compute the effective mean atmospheric transmittance of Raipur (Qin et al., 2001; Sun et al., 2010):

$$
T_{a}=17.9769+0.91715 T_{0}
$$

LST is retrieved from Landsat 5 TM, Landsat 7 ETM+, and Landsat 8 OLI/TIRS satellite data by using the following equations (Qin et al., 2001):

$$
\begin{gathered}
T_{s}=\frac{\left[a(1-C-D)+(b(1-C-D)+C+D) T_{b}-D T_{a}\right]}{C} \\
C=\varepsilon \tau \\
D=(1-\tau)[1+(1-\varepsilon) \tau]
\end{gathered}
$$

where, $\varepsilon$ is the land surface emissivity, $\tau$ is the total atmospheric transmittance, $T_{b}$ is the at-sensor brightness temperature, $T_{a}$ is the mean atmospheric temperature, $T_{0}$ is the near-surface air temperature, $T_{s}$ is the land surface temperature, $a=-67.355351, b=0.458606$.

Figure 2 shows the flowchart of methodology of the present study which clearly presents the steps of the LST retrieval process.

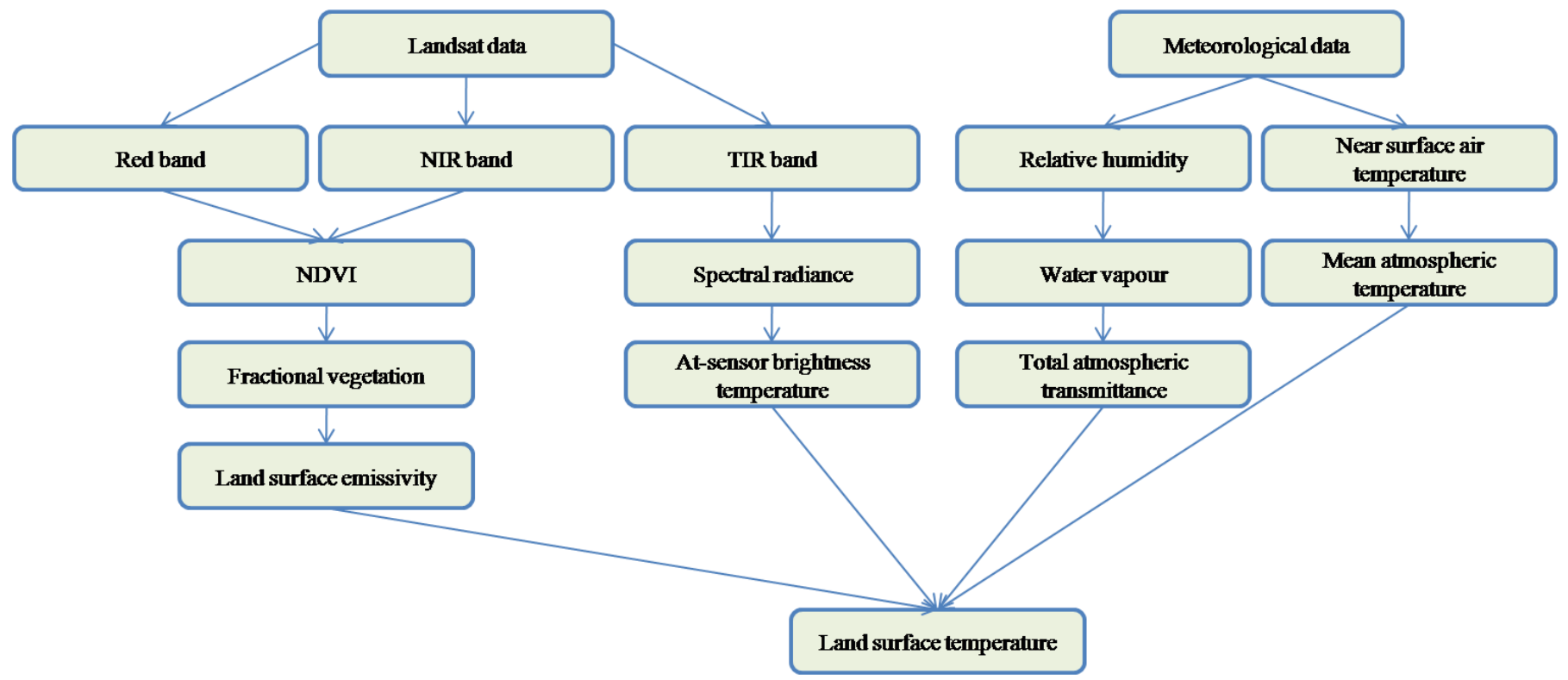

Figure 2 - Flowchart showing the methodology of the present study. Source: Author (2021). 


\section{Determination of NDVI}

Here, NDVI was selected as a normalized difference spectral index in the research work (Tucker, 1979). NDVI is determined by the red and NIR bands. For TM and ETM+ data, band 3 is used as a red band and band 4 is used as a NIR band, respectively. For OLI/TIRS data, band 4 and band 5 are used as red and NIR bands, respectively (Table 4). The value of NDVI ranges between -1 and +1 . Generally, the negative value of NDVI indicates the water surfaces. Positive NDVI shows vegetation surface. The increasing positive value of NDVI indicates the increase of greenness in plants.

Table 4 - Description of normalized difference vegetation index (NDVI)

\begin{tabular}{llll}
\hline Acronym & Description & Formulation & References \\
\hline NDVI & Normalized difference & NIR $-\operatorname{Re} d$ & Tucker 1979 \\
& vegetation index & NIR $+\operatorname{Re} d$ & \\
\hline
\end{tabular}

Source: Author (2020).

\section{Results and discussion}

\section{Monthly variation in LST distribution}

Table 5 shows a clear observation of monthly change in the mean LST values. In this table, the mean LST of each image is shown. The mean LST of every month was also determined. In this way, the mean LST values for ten months (no cloud-free data was available for July and August) were presented.

It is seen from Table 5 that the mean LST of the city was above $32^{\circ} \mathrm{C}$ mean LST for all the months from March-May of 1992, 2001-02, 2004-05, 2008-11, 2013, 2016-17, and 2019. June and September of 2005, 2006, and 2009 have more mean LST values than the earlier and later years. The scenario was completely different from October to February, where that the mean LST of the city was below $28^{\circ} \mathrm{C}$ LST. April $\left(38.79^{\circ} \mathrm{C}\right.$ mean LST), May $\left(36.65^{\circ} \mathrm{C}\right.$ mean LST), June $\left(34.56^{\circ} \mathrm{C}\right.$ mean LST), and March $\left(32.11^{\circ} \mathrm{C}\right.$ mean LST) - these four months have an average value of $>35^{\circ} \mathrm{C}$ mean LST throughout the entire period of study. February $\left(27.88^{\circ} \mathrm{C}\right.$ mean LST), October $\left(27.23^{\circ} \mathrm{C}\right.$ mean LST), September $\left(27.18^{\circ} \mathrm{C}\right.$ mean LST), and November $\left(25.83^{\circ} \mathrm{C}\right.$ mean LST) - these four months have an average value of $25-28^{\circ} \mathrm{C}$ mean LST throughout the entire time. Only December $\left(23.76^{\circ} \mathrm{C}\right.$ mean LST) and January $\left(23.01^{\circ} \mathrm{C}\right.$ mean LST) months have an average value of $<24^{\circ} \mathrm{C}$ mean LST for the period. The average value of the highest and the lowest mean LST from 1988 to 2019 is observed in April and January, respectively. The northwest and southeast parts of the study area exhibit high LST. These parts also have a low percentage of urban vegetation and a high percentage of built-up areas and bare land. It shows that the proportion of vegetation reduced significantly with time.

Figure 3 shows the line graph of LST in different months from 1988 o 2019. October, November, and December present an almost similar pattern of LST distribution. January and February show an almost similar trend in their LST graph. A similarity also has been seen in the mean LST graph of March, April, and May. The LST graph of June shows a negative trend, while September shows a positive trend. 
A long-term monthly assessment of land surface temperature and normalized difference vegetation index using Landsat data

Table 5 - Monthly distribution of mean LST $\left({ }^{\circ} \mathrm{C}\right)$ for the entire Raipur City from 1988 to 2019

\begin{tabular}{|c|c|c|c|c|c|c|c|c|c|}
\hline January & LST $\left({ }^{\circ} \mathrm{C}\right)$ & February & LST $\left({ }^{\circ} \mathrm{C}\right)$ & March & LST $\left({ }^{\circ} \mathrm{C}\right)$ & April & LST $\left({ }^{\circ} \mathrm{C}\right)$ & May & LST $\left({ }^{\circ} \mathrm{C}\right)$ \\
\hline 1988-Jan-21 & 24.52 & 1989-Feb-24 & 28.31 & 1989-Mar-12 & 28.14 & 1990-Apr-16 & 40.87 & 1991-May-21 & 36.63 \\
\hline 1990-Jan-10 & 24.42 & 1990-Feb-11 & 25.26 & 1990-Mar-15 & 30.96 & 1992-Apr-21 & 41.19 & 2002-May-11 & 40.92 \\
\hline 1992-Jan-16 & 21.33 & 1991-Feb-14 & 23.98 & 1991-Mar-18 & 29.50 & 1995-Apr-14 & 34.63 & 2004-May-24 & 40.74 \\
\hline 1993-Jan-18 & 23.41 & 1992-Feb-17 & 25.30 & 1992-Mar-20 & 32.84 & 2001-Apr-22 & 41.34 & 2005-May-11 & 38.72 \\
\hline 1996-Jan-27 & 22.08 & 1993-Feb-19 & 28.42 & 2003-Mar-11 & 29.49 & 2002-Apr-25 & 38.85 & 2006-May-14 & 28.43 \\
\hline 2005-Jan-19 & 22.08 & 2002-Feb-20 & 30.39 & 2004-Mar-21 & 36.48 & 2003-Apr-12 & 31.28 & 2007-May-17 & 36.20 \\
\hline 2007-Jan-25 & 26.37 & 2004-Feb-18 & 26.64 & 2007-Mar-14 & 27.57 & 2004-Apr-22 & 36.80 & 2008-May-19 & 38.36 \\
\hline 2009-Jan-14 & 17.15 & 2006-Feb-23 & 32.95 & 2009-Mar-19 & 33.79 & 2009-Apr-20 & 39.74 & 2009-May-22 & 33.20 \\
\hline 2011-Jan-20 & 23.03 & 2009-Feb-15 & 31.01 & 2014-Mar-17 & 31.68 & 2010-Apr-23 & 40.63 & 2010-May-25 & 36.11 \\
\hline 2015-Jan-15 & 23.49 & 2010-Feb-18 & 22.67 & 2015-Mar-20 & 32.83 & 2016-Apr-23 & 42.97 & $2011-M a y-12$ & 39.80 \\
\hline \multirow[t]{7}{*}{ 2018-Jan-23 } & 25.26 & 2015-Feb-16 & 29.75 & 2016-Mar-22 & 37.00 & 2017-Apr-10 & 38.37 & 2013-May-17 & 40.28 \\
\hline & & 2016-Feb-19 & 24.60 & 2017-Mar-25 & 37.06 & & & 2014-May-20 & 34.91 \\
\hline & & 2017-Feb-21 & 32.45 & 2018-Mar-12 & 30.09 & & & 2015-May-23 & 36.42 \\
\hline & & 2018-Feb-24 & 31.05 & & & & & 2016-May-25 & 37.22 \\
\hline & & 2019-Feb-11 & 25.37 & & & & & 2017-May-12 & 33.33 \\
\hline & & 1989-Feb-24 & 28.31 & & & & & 2018-May-15 & 31.42 \\
\hline & & & & & & & & 2019-May-18 & 40.21 \\
\hline Mean & 23.01 & Mean & 27.88 & Mean & 32.11 & Mean & 38.79 & Mean & 36.64 \\
\hline June & LST $\left({ }^{\circ} \mathrm{C}\right)$ & September & LST $\left({ }^{\circ} \mathrm{C}\right)$ & October & LST $\left({ }^{\circ} \mathrm{C}\right)$ & November & LST $\left({ }^{\circ} \mathrm{C}\right)$ & December & LST $\left({ }^{\circ} \mathrm{C}\right)$ \\
\hline 2005-Jun-12 & 38.66 & 1996-Sep-23 & 24.09 & 1988-Oct-19 & 28.86 & 1988-Nov-20 & 24.27 & 1988-Dec-22 & 23.96 \\
\hline 2006-Jun-15 & 35.43 & 2001-Sep-21 & 26.13 & 1991-Oct-12 & 24.98 & 1989-Nov-23 & 25.16 & 1992-Dec-17 & 22.34 \\
\hline 2009-Jun-23 & 33.05 & 2002-Sep-16 & 28.81 & 1992-Oct-14 & 24.61 & 1991-Nov-13 & 23.64 & 1994-Dec-23 & 18.55 \\
\hline \multirow[t]{13}{*}{ 2018-Jun-16 } & 31.08 & 2014-Sep-25 & 29.67 & 1996-Oct-25 & 22.56 & 1993-Nov-18 & 24.47 & 1995-Dec-10 & 21.49 \\
\hline & & & & 2001-Oct-15 & 30.12 & 1996-Nov-10 & 23.15 & 2000-Dec-15 & 26.81 \\
\hline & & & & 2001-Oct-23 & 26.85 & 1999-Nov-11 & 29.16 & 2002-Dec-21 & 27.09 \\
\hline & & & & 2004-Oct-15 & 27.56 & 2004-Nov-16 & 28.45 & 2004-Dec-18 & 25.76 \\
\hline & & & & 2006-Oct-21 & 26.30 & 2005-Nov-19 & 26.72 & 2006-Dec-24 & 23.35 \\
\hline & & & & 2009-Oct-13 & 27.10 & 2006-Nov-22 & 26.40 & 2008-Dec-13 & 25.71 \\
\hline & & & & $2011-$ Oct-19 & 28.30 & 2008-Nov-11 & 27.38 & 2009-Dec-16 & 23.59 \\
\hline & & & & 2015-Oct-14 & 27.61 & 2013-Nov-25 & 26.09 & 2010-Dec-19 & 22.31 \\
\hline & & & & 2016-Oct-16 & 30.02 & 2014-Nov-12 & 23.47 & 2013-Dec-11 & 24.62 \\
\hline & & & & 2018-Oct-22 & 29.01 & 2016-Nov-17 & 27.18 & 2016-Dec-19 & 24.60 \\
\hline & & & & & & 2017-Nov-20 & 26.28 & 2017-Dec-22 & 24.02 \\
\hline & & & & & & 2019-Nov-10 & 25.60 & 2018-Dec-25 & 21.17 \\
\hline & & & & & & & & 2019-Dec-12 & 24.74 \\
\hline Mean & 34.56 & Mean & 27.18 & Mean & 27.22 & Mean & 25.83 & Mean & 23.76 \\
\hline
\end{tabular}

Source: Author (2021). 


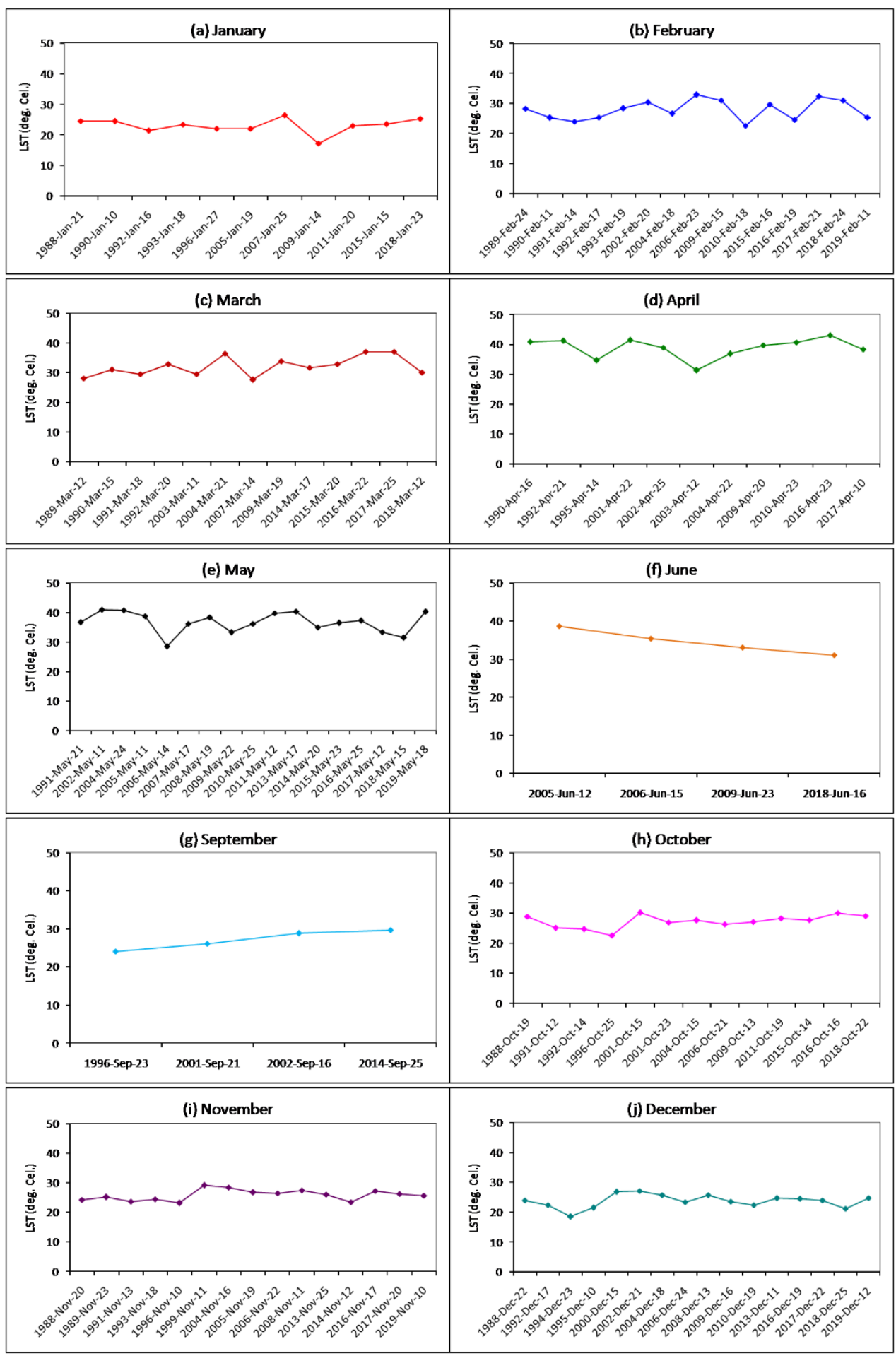

Figure 3 - Line graphs for monthly variation of LST ( ${ }^{\circ}$ C) from1988 to 2019: (a) January (b) February (c) March (d) April (e) May (f) June (g) September (h) October (i) November (j) December. Source: Author (2021). 


\section{Monthly variation on LST-NDVI relationship}

Table 6 - Monthly variation of LST-NDVI correlation coefficient(1988-2019) (significant at 0.05 level)

\begin{tabular}{|c|c|c|c|c|c|c|c|c|c|}
\hline January & $\begin{array}{l}\text { Correlation } \\
\text { coefficient }\end{array}$ & February & $\begin{array}{l}\text { Correlation } \\
\text { coefficient }\end{array}$ & March & $\begin{array}{l}\text { Correlation } \\
\text { coefficient }\end{array}$ & April & $\begin{array}{l}\text { Correlation } \\
\text { coefficient }\end{array}$ & May & $\begin{array}{l}\text { Correlation } \\
\text { coefficient }\end{array}$ \\
\hline 1988-Jan-21 & -0.31 & 1989-Feb-24 & -0.39 & 1989-Mar-12 & -0.43 & 1990-Apr-16 & -0.52 & 1991-May-21 & -0.43 \\
\hline 1990-Jan-10 & -0.36 & 1990-Feb-11 & -0.38 & 1990-Mar-15 & -0.43 & 1992-Apr-21 & -0.53 & 2002-May-11 & -0.56 \\
\hline 1992-Jan-16 & -0.35 & 1991-Feb-14 & -0.12 & 1991-Mar-18 & -0.40 & 1995-Apr-14 & -0.38 & 2004-May-24 & -0.46 \\
\hline 1993-Jan-18 & -0.38 & 1992-Feb-17 & -0.29 & 1992-Mar-20 & -0.40 & 2001-Apr-22 & -0.65 & 2005-May-11 & -0.54 \\
\hline 1996-Jan-27 & -0.30 & 1993-Feb-19 & -0.37 & 2003-Mar-11 & -0.41 & 2002-Apr-25 & -0.57 & 2006-May-14 & -0.46 \\
\hline 2005-Jan-19 & -0.21 & 2002-Feb-20 & -0.44 & 2004-Mar-21 & -0.49 & 2003-Apr-12 & -0.39 & 2007-May-17 & -0.33 \\
\hline 2007-Jan-25 & -0.21 & 2004-Feb-18 & -0.30 & 2007-Mar-14 & -0.38 & 2004-Apr-22 & -0.51 & 2008-May-19 & -0.48 \\
\hline 2009-Jan-14 & -0.25 & 2006-Feb-23 & -0.31 & 2009-Mar-19 & -0.54 & 2009-Apr-20 & -0.56 & 2009-May-22 & -0.44 \\
\hline $2011-J a n-20$ & -0.18 & 2009-Feb-15 & -0.36 & 2014-Mar-17 & -0.42 & 2010-Apr-23 & -0.52 & 2010-May-25 & -0.47 \\
\hline 2015-Jan-15 & -0.27 & 2010-Feb-18 & -0.24 & 2015-Mar-20 & -0.36 & 2016-Apr-23 & -0.46 & 2011-May-12 & -0.56 \\
\hline \multirow[t]{7}{*}{ 2018-Jan-23 } & -0.15 & 2015-Feb-16 & -0.16 & 2016-Mar-22 & -0.40 & 2017-Apr-10 & -0.51 & 2013-May-17 & -0.43 \\
\hline & & 2016-Feb-19 & -0.21 & 2017-Mar-25 & -0.43 & & & 2014-May-20 & -0.41 \\
\hline & & 2017-Feb-21 & -0.30 & 2018-Mar-12 & -0.37 & & & 2015-May-23 & -0.34 \\
\hline & & 2018-Feb-24 & -0.28 & & & & & 2016-May-25 & -0.38 \\
\hline & & 2019-Feb-11 & -0.21 & & & & & 2017-May-12 & -0.29 \\
\hline & & 1989-Feb-24 & -0.39 & & & & & 2018-May-15 & -0.45 \\
\hline & & & & & & & & 2019-May-18 & -0.43 \\
\hline Mean & -0.24 & Mean & -0.29 & Mean & -0.40 & Mean & -0.51 & Mean & -0.44 \\
\hline June & $\begin{array}{l}\text { Correlation } \\
\text { coefficient }\end{array}$ & September & $\begin{array}{l}\text { Correlation } \\
\text { coefficient }\end{array}$ & October & $\begin{array}{l}\text { Correlation } \\
\text { coefficient }\end{array}$ & November & $\begin{array}{l}\text { Correlation } \\
\text { coefficient }\end{array}$ & December & $\begin{array}{l}\text { Correlation } \\
\text { coefficient }\end{array}$ \\
\hline 2005-Jun-12 & -0.51 & 1996-Sep-23 & -0.54 & 1988-Oct-19 & -0.69 & 1988-Nov-20 & -0.41 & 1988-Dec-22 & -0.20 \\
\hline 2006-Jun-15 & -0.46 & 2001-Sep-21 & -0.58 & 1991-Oct-12 & -0.63 & 1989-Nov-23 & -0.29 & 1992-Dec-17 & -0.15 \\
\hline 2009-Jun-23 & -0.42 & 2002-Sep-16 & -0.56 & 1992-Oct-14 & -0.68 & 1991-Nov-13 & -0.38 & 1994-Dec-23 & -0.24 \\
\hline \multirow[t]{13}{*}{ 2018-Jun-16 } & -0.46 & 2014-Sep-25 & -0.53 & 1996-Oct-25 & -0.64 & 1993-Nov-18 & -0.19 & 1995-Dec-10 & -0.09 \\
\hline & & & & 2001-Oct-15 & -0.66 & 1996-Nov-10 & -0.40 & 2000-Dec-15 & -0.18 \\
\hline & & & & 2001-Oct-23 & -0.58 & 1999-Nov-11 & -0.48 & 2002-Dec-21 & -0.29 \\
\hline & & & & 2004-Oct-15 & -0.63 & 2004-Nov-16 & -0.35 & 2004-Dec-18 & -0.10 \\
\hline & & & & 2006-Oct-21 & -0.51 & 2005-Nov-19 & -0.31 & 2006-Dec-24 & -0.23 \\
\hline & & & & 2009-Oct-13 & -0.64 & 2006-Nov-22 & -0.23 & 2008-Dec-13 & -0.12 \\
\hline & & & & 2011 -Oct-19 & -0.63 & 2008-Nov-11 & -0.41 & 2009-Dec-16 & -0.20 \\
\hline & & & & 2015-Oct-14 & -0.61 & 2013-Nov-25 & -0.44 & 2010-Dec-19 & -0.24 \\
\hline & & & & 2016-Oct-16 & -0.53 & 2014-Nov-12 & -0.52 & 2013-Dec-11 & -0.19 \\
\hline & & & & 2018-Oct-22 & -0.63 & 2016-Nov-17 & -0.44 & 2016-Dec-19 & -0.21 \\
\hline & & & & & & 2017-Nov-20 & -0.45 & 2017-Dec-22 & -0.30 \\
\hline & & & & & & 2019-Nov-10 & -0.59 & 2018-Dec-25 & -0.22 \\
\hline & & & & & & & & 2019-Dec-12 & -0.40 \\
\hline Mean & -0.47 & Mean & -0.55 & Mean & -0.62 & Mean & -0.39 & Mean & -0.21 \\
\hline
\end{tabular}

Source: Author (2021).

Table 6 represents a monthly variation of Pearson's linear correlation method between LST and NDVI significant at 0.05 level. On average, October (-0.62), September (-0.55), and April (-0.51) months build a strong negative correlation. June (-0.47), May (-0.44), March (-0.44), and November (-0.39) months have a moderate negative correlation. A weak negative correlation was found in February (-0.29), January (-0.24), and December $(-0.21)$ months. The main reason behind the strong to moderate LST-NDVI correlation in March-November is the presence of high intensity of moisture and chlorophyll content in green vegetation. Dry months reduce the strength of regression, while wet months enhance the strength of the LST-NDVI regression. Hence, the climatic condition and surface material influence the LST-NDVI correlation analysis. 


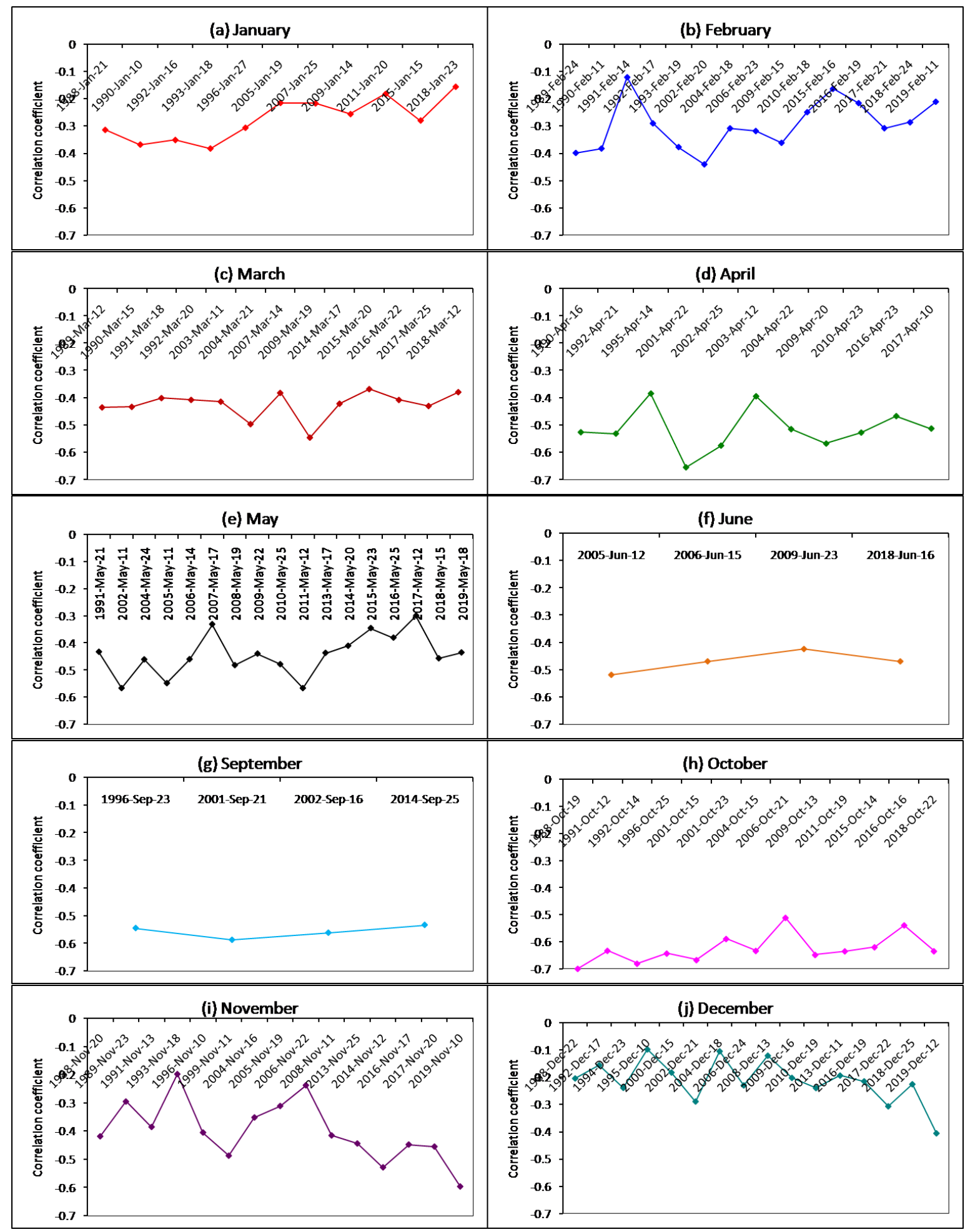

Figure 4 - Line graphs for monthly variation of LST-NDVI relationship (1988-2019): (a) January (b) February (c) March (d) April (e) May (f) June (g) September (h) October (i) November (j) December. Source: Author (2021).

Figure 4 shows the line graphs for monthly variation of LST-NDVI relationships. June and September months show a smooth convex and concave trend, respectively due to wet weather. The line graphs of October, November, and December show more fluctuation due to more differences in atmospheric components. The line graphs of January and March look almost similar. February, April, and May present similar trends of LST. 
Liang et al. (2012) presented similar types of negative NDVI-LST correlation in Guilin City, China. In high latitudes, positive LST-NDVI relationships have been observed as the presence of vegetation increases the value of LST in high latitudes where the winter season is severe (Karnieli et al., 2006). Yue et al. (2007) showed that the LST-NDVI relationship in Shanghai City, China was negative and was different in different LULC types like the relationship was strong negative on vegetation. Sun and Kafatos (2007) stated that the LST-NDVI correlation was positive in the winter season while it was negative in the summer season as the winter season produces the lowest LST on the rock surface and dry soil and vice-versa in the summer season. This relationship was also negative in Mashhad, Iran as it is a dry tropical city (Gorgani et al., 2013). The relationship was strongly negative in Berlin City for any season (Marzban et al., 2018). This correlation tends to be more negative with the increase of surface moisture as in the wet season more green and healthy vegetation is produced (Moran et al., 1994; Lambin \& Ehrlich, 1996; Prehodko \& Goward, 1997; Sandholt et al., 2002). The present study also found a negative LST-NDVI correlation for all the months as it is a humid tropical city. The value of the correlation coefficient is inversely related to the surface moisture content, i.e., the negativity of the relationship increases with the increase of surface moisture content.

\section{Conclusions}

The present study estimates the monthly variation of LST distribution in Raipur City, India using one hundred and eighteen Landsat datasets from 1988 to 2019. April, May, June, and March present higher LST values than the rest of the months. The present study also assesses the monthly correlation of LST and NDVI in Raipur City. In general, the results show that LST is inversely related to NDVI, irrespective of any month. From March to November, the correlation is strong to moderate negative, whereas it is found weak negative in the winter season (December to February). The presence of healthy green plants and high moisture content in the air is the main responsible factors for strong negativity. The study is useful for the environmentalists and urban planners for future ecological planning from several points of view. Special attention may be taken in March, April, May, and June to increase the negativity of the relationship by plantation. Simultaneously, more trees can be planted in December, January, and February for generating pleasant weather. Moreover, some commercial activities may be decreased in the winter months as at that time the city remains dry and more polluted. Special emphasis should be taken on the transport and industrial sectors as these sectors are mainly responsible for generating high LST. Mass transport system must be encouraged instead of the private transport system. The area under the park, urban vegetation, water bodies, and wetland must be increased at any cost as these changes can bring ecological comfort to the city. The unused fallow lands should be converted into vegetation and water area. It will be beneficial to the residents if any public and private initiatives have to be taken on seasonal plantation programmes along the roadways and barren lands.

\section{References}

Alexander, C. (2020). Normalised difference spectral indices and urban land cover as indicators of land surface temperature (LST). Int J Appl Earth Obs Geoinf, 86, 102013. https://doi.org/10.1016/j.jag.2019.102013.

Carlson, T. N., \& Ripley, D. A. (1997). On the Relation between NDVI, Fractional Vegetation Cover, and Leaf Area Index. Remote Sens Environ, 62(3), 241-252. https://doi.org/10.1016/S0034-4257(97)00104-1.

Chen, XL, Zhao, HM, Li, PX, \& Yi, ZY. (2006). Remote sensing image-based analysis of the relationship between urban heat island and land use/cover changes. Remote Sens Environ, 104(2), 133-146. https://doi.org/10.1016/j.rse.2005.11.016

Cui, L., Wang, L., Qu, S., Singh, R. P., Lai, Z., \& Yao, R. (2019). Spatiotemporal extremes of temperature and precipitation during 1960-2015 in the Yangtze River Basin (China) and impacts on vegetation dynamics. Theor Appl Climatol, 136(1-2), 675-692. https://doi.org/10.1007/s00704-018-2519-0. 
Cui, L., Wang, L., Qu, S., Singh, R. P., Lai, Z., Jiang, L., \& Yao, R. (2019). Association analysis between spatiotemporal variation of vegetation greenness and precipitation/temperature in the Yangtze River Basin (China). Environ Sci Pollut Res, 25(22), 2186721878. https://doi.org/10.1007/s11356-018-2340-4.

Fatemi, M., \& Narangifard, M. (2019). Monitoring LULC changes and its impact on the LST and NDVI in District 1 of Shiraz City. Arab J Geosci, 12, 127. https://doi.org/10.1007/s12517-019-4259-6.

Ferrelli, F., Huamantinco, M. A., Delgado, D. A., \& Piccolo, M. C. (2018). Spatial and temporal analysis of the LST-NDVI relationship for the study of land cover changes and their contribution to urban planning in Monte Hermoso, Argentina. Doc Anal Geogr, 64(1), 25-47. https://doi.org/10.5565/rev/dag.355.

Ghobadi, Y., Pradhan, B., Shafri, H. Z. M., \& Kabiri, K. (2014). Assessment of spatial relationship between land surface temperature and land use/cover retrieval from multi-temporal remote sensing data in South Karkheh Sub-basin, Iran. Arab J Geosci, 8(1), 525-537. https://doi.org/10.1007/s12517-013-1244-3.

Gorgani, S. A., Panahi, M., \& Rezaie, F. (2013). The relationship between NDVI and LST in the Urban area of Mashhad, Iran. In International Conference on Civil Engineering Architecture and Urban Sustainable Development. November, Tabriz, Iran.

Govil, H., Guha, S., Dey, A., \& Gill, N. (2019). Seasonal evaluation of downscaled land surface temperature: A case study in a humid tropical city. Heliyon, 5(6), e01923. https://doi.org/10.1016/j.heliyon.2019.e01923.

Govil, H., Guha, S., Diwan, P., Gill, N., \& Dey, A. (2020). Analyzing Linear Relationships of LST with NDVI and MNDISI Using Various Resolution Levels of Landsat 8 OLI/TIRS Data. In Sharma N., Chakrabarti A., Balas V. (Eds.), Data Management, Analytics and Innovation. Advances in Intelligent Systems and Computing (Vol. 1042, p. 171-184). Singapore: Springer.

https://doi.org/10.1007/978-981-32-9949-8_13

Goward, S. N., Xue, Y. K., \& Czajkowski, K. P. (2002). Evaluating Land Surface Moisture Conditions from the Remotely Sensed Temperature/Vegetation Index Measurements: An Exploration with the Simplified Simple Biosphere Model. Remote Sens Environ,79, 225-242. https://doi:10.1016/S0034-4257(01)00275-9.

Guha, S. (2016). Capability of NDVI technique in detecting mangrove vegetation. Int J Adv Biol Res, 6(2), 253-258.

Guha, S. (2021). Dynamic seasonal analysis on LST-NDVI relationship and ecological health of Raipur City, India. Ecosyst Health Sustain. 7(1): 1927852. https://doi.org/10.1080/20964129.2021.1927852.

Guha, S., \& Govil, H. (2019). Evaluation of ASTER TIR data-based lithological indices in Malanjkhand Copper Mines of Madhya Pradesh, India. Appl Earth Sci, 129(1), 3-8. https://doi.org/10.1080/25726838.2019.1684018.

Guha, S., \& Govil, H. (2020). Seasonal impact on the relationship between land surface temperature and normalized difference vegetation index in an urban landscape. Geocarto Int. https://doi.org/10.1080/10106049.2020.1815867.

Guha, S., \& Govil, H. (2021a). Annual assessment on the relationship between land surface temperature and six remote sensing indices using Landsat data from 1988 to 2019. Geocarto Int. https://doi.org/10.1080/10106049.2021.1886339.

Guha, S., \& Govil, H. (2021b). COVID-19 lockdown effect on land surface temperature and normalized difference vegetation index. Geomat Nat Haz Risk, 12(1): 1082-1100. https://doi.org/10.1080/19475705.2021.1914197.

Guha, S., \& Govil, H. (2021c). An assessment on the relationship between land surface temperature and normalized difference vegetation index. Environ Dev Sustain,23(2): 1944-1963. https://doi.org/10.1007/s10668-020-00657-6.

Guha, S., Govil, H., \& Besoya, M. (2020). An investigation on seasonal variability between LST and NDWI in an urban environment using Landsat satellite data. Geomat Nat Haz Risk, 11(1), 1319-1345.

https://doi.org/10.1080/19475705.2020.1789762.

Guha, S., Govil, H., \& Diwan, P. (2019). Analytical study of seasonal variability in land surface temperature with normalized difference vegetation index, normalized difference water index, normalized difference built-up index, and normalized multiband drought index. J Appl Remote Sens, 13(2), 024518. https://doi.org/1010.1117/1.JRS.13.024518.

Guha, S., Govil, H., \& Diwan, P. (2020). Monitoring LST-NDVI Relationship Using Premonsoon Landsat Datasets. AdvMeteorol, 2020, 4539684. https://doi.org/10.1155/2020/4539684. 
A long-term monthly assessment of land surface temperature and normalized difference vegetation index using Landsat data

Guha, S., Govil, H., \& Mukherjee, S. (2017). Dynamic analysis and ecological evaluation of urban heat islands in Raipur city, India. J Appl Remote Sens, 11(3), 036020. https://doi.org/10.1117/1.JRS.11.036020.

Guha, S., Govil, H., Dey, A., \& Gill, N. (2018). Analytical study of land surface temperature with NDVI and NDBI using Landsat 8 OLI/TIRS data in Florence and Naples city, Italy. Eur J Remote Sens, 51(1), 667-678.

https://doi:10.1080/22797254.2018.1474494.

Guha, S., Govil, H., Dey, A., \& Gill, N. (2020). A case study on the relationship between land surface temperature and land surface indices in Raipur City, India. Geogr Tidsskr,120(1), 35-50. https://doi.org/10.1080/00167223.2020.1752272.

Guha, S., Govil, H., Gill, N., \& Dey, A. (2020a). A long-term seasonal analysis on the relationship between LST and NDBI using Landsat data. Quatern Int. 575-576: 249-258. https://doi.org/10.1016/j.quaint.2020.06.041

Guha, S., Govil, H., Gill, N., \& Dey, A. (2020b). Analysing the Capability of NCI Technique in Change Detection Using High-and Medium-Resolution Multispectral Data. In S. Sahdev, R. B. Singh, \& M. Kumar (Eds.), Geoecology of Landscape Dynamics (p. 133147). Springer, Singapore. https://doi.org/10.1007/978-981-15-2097-6_10.

Guha, S., Govil, H., Gill, N., \& Dey, A. (2020c). Analytical study on the relationship between land surface temperature and land use/land cover indices. Ann GIS, 26(2), 201-216. https://doi.org/10.1080/19475683.2020.1754291.

Gui, X., Wang, L., Yao, R., Yu, D., \& Li, C. (2019). Investigating the urbanization process and its impact on vegetation change and urban heat island in Wuhan, China. Environ Sci Pollut Res, 26(30), 30808-30825. https://doi.org/10.1007/s11356-019-06273-w.

Gutman, G., \& Ignatov, A. (1998). The Derivation of the Green Vegetation Fraction from NOAA/ AVHRR Data for Use in Numerical Weather Prediction Models. Int J Remote Sens, 19(8), 1533-1543. https://doi:10.1080/014311698215333.

Hao, X., Li, W., \& Deng, H. (2016). The oasis effect and summer temperature rise in arid regions-case study in Tarim Basin. Sci Rep, 6, 35418. https://doi.org/10.1038/srep35418.

Hou, G. L., Zhang, H. Y., Wang, Y. Q., Qiao, Z. H., \& Zhang, Z. X. (2010). Retrieval and Spatial Distribution of Land Surface Temperature in the Middle Part of Jilin Province Based on MODIS Data. SciGeogr Sin, 30, 421-427.

Jamei, Y., Rajagopalan, P., \& Sun, Q. C. (2019). Spatial structure of surface urban heat island and its relationship with vegetation and built-up areas in Melbourne, Australia. Sci Total Environ, 659, 1335-1351.

https://doi.org/10.1016/j.scitotenv.2018.12.308.

Karnieli, A., Bayasgalan, M., Bayarjargal, Y., Agam, N., Khudulmur, S., \& Tucker, C. J. (2006). Comments on the use of the Vegetation Health Index over Mongolia. Int J Remote Sens, 27(10), 2017-2024. https://doi:10.1080/01431160500121727.

Kikon, N., Singh, P., Singh, S. K., \& Vyas, A. (2016). Assessment of urban heat islands (UHI) of Noida City, India using multitemporal satellite data. Sustain Cities Soc, 22, 19-28. https://doi.org/10.1016/j.scs.2016.01.005.

Kumar, D., \& Shekhar, S. (2015). Statisticalanalysisofland surface temperature-vegetation indexes relationship through thermal remote sensing. Ecotox Environ Safe, 121, 39-44. https://doi.org/10.1016/j.ecoenv.2015.07.004.

Lambin, E. F., \& Ehrlich, D. (1996). The Surface Tenperature-Vegetation Index Space for Land Use and Land Cover Change analysis. Int J Remote Sens, 17, 463-487. https://doi.org/10.1080/01431169608949021.

Li, J. (2006). Estimating land surface temperature from Landsat-5 TM. Remote Sens Technol Appl,21, 322-326.

Li, W. F., Cao, Q. W., Kun, L., \& Wu, J. S. (2017). Linking potential heat source and sink to urban heat island: Heterogeneous effects of landscape pattern on land surface temperature. Sci Total Environ, 586, 457-465.

https://doi.org/10.1016/j.scitotenv.2017.01.191.

Liang, B. P., Li, Y., \& Chen, K. Z. (2012). A Researchon Land Features and Correlation between NDVI and Land Surface Temperature in Guilin City. Remote Sens Tech Appl, 27, 429-435.

Marzban, F., Sodoudi, S., \& Preusker, R. (2018). The influence of land-cover type on the relationship between LST-NDVI and LST-Tair. Int J Remote Sens, 39(5), 1377-1398. https://doi.org/10.1080/01431161.2017.1462386.

Mathew, A., Khandelwal, S., \& Kaul, N. (2017). Investigating spatial and seasonal variations of urban heat island effect over Jaipur city and its relationship with vegetation, urbanization and elevation parameters. Sustain Cities Soc, 35, 157-177. https://doi.org/10.1016/j.scs.2017.07.013. 
Mathew, A., Khandelwal, S., \& Kaul, N. (2018). Spatio-temporal variations of surface temperatures of Ahmedabad city and its relationship with vegetation and urbanization parameters as indicators of surface temperatures. Remote Sens Appl Soc Environ, 11,119-139. https://doi.org/10.1016/j.rsase.2018.05.003.

Mondal, A., Guha, S., Mishra, P. K., \& Kundu, S. (2011). Land use/Land cover changes in Hugli Estuary using Fuzzy CMean algorithm. Int J Geomat Geosci, 2(2), 613-626.

Moran, M. S., Clarke, T. R., Inouie, Y., \& Vidal, A. (1994). Estimating Crop Water-Deficit using the Relation between Surface AirTemperature and Spectral Vegetation Index. Remote Sens Environ, 49, 246-263. https://doi.org/10.1016/0034-

4257(94)90020-5.

Prehodko, L., \& Goward, S. N. (1997). Estimation of Air Temperature from Remotely Sensed Surface Observations. Remote Sens Environ, 60, 335-346. https://doi:10.1016/S0034-4257 (96)00216-7.

Qin, Z., Karnieli, A., \& Barliner, P. (2001). A Mono-WindowAlgorithm for Retrieving Land Surface Temperature from Landsat TM Data and Its Application to the Israel-Egypt Border Region. Int J Remote Sens, 22(18), 3719-3746.

https://doi:10.1080/01431160010006971.

Qu, S., Wang, L., Lin, A., Yu, D, Yuan, M., \& Li, C. (2020). Distinguishing the impacts of climate change and anthropogenic factors on vegetation dynamics in the Yangtze River Basin, China. Ecol Indic, 108, 105724.

https://doi.org/10.1016/j.ecolind.2019.105724.

Qu, S., Wang, L., Lin, A., Zhu, H., \& Yuan, M. (2018). What drives thevegetation restoration in Yangtze River basin, China: Climate change or anthropogenic factors? Ecol Indic, 90, 438-450. https://doi.org/10.1016/j.ecolind.2018.03.029.

Sandholt, I., Rasmussen, K., \& Andersen, J. (2002). A simple interpretation of the Surface Temperature/Vegetation Index Space for Assessment of Surface Moisture Status. Remote Sens Environ, 79, 213-224. https://doi.org/10.1016/s0034-

4257(01)00274-7.

Sannigrahi, S., Bhatt, S., Rahmat, S., Uniyal, B., Banerjee, S., Chakraborti, S., Jha, S., Lahiri, S., Santra, K., \& Bhatt, A. (2018). Analyzing the role of biophysical compositions in minimizing urban land surface temperature and urban heatingUrban Climate, 24, 803-819. https://doi.org/10.1016/j.uclim.2017.10.002.

Sekertekin, A., \& Bonafoni, S. (2020). Land surface temperature retrieval from landsat 5, 7, and 8 over rural areas: assessment of different retrieval algorithms and emissivity models and toolbox implementation. Remote Sens, 12(2), 294.

Shigeto, K. (1994). Relation between vegetation, surface temperature, and surface composition in the Tokyo region during winter. Remote Sens Environ, 50(1), 52-60. https://doi.org/10.1016/0034-4257(94)90094-9

Singh, P., Kikon, N., \& Verma, P. (2017). Impact of land use change and urbanization on urban heat island in Lucknow city, Central India. A remote sensing based estimate. Sustain Cities Soc, 32, 100-114. https://doi.org/10.1016/j.scs.2017.02.018.

Sobrino, J. A., Jimenez-Munoz, J. C., \& Paolini, L. (2004). Land surface temperature retrieval from Landsat TM5. Remote Sens Environ,90(4), 434-440. https://doi.org/10.1016/j.rse.2004.02.003.

Sun, D., \& Kafatos, M. (2007). Note on the NDVI-LST Relationship and the Use of Temperature-Related Drought Indices over North America. Geophys Res Lett, 34(24), L24406. http://doi.org/10.1029/2007GL031485.

Sun, Q., Tan, J., \& Xu, Y. (2010). An ERDAS image processing method for retrieving LST and describing urban heat evolution: A case study in the Pearl River Delta Region in South China. Environ Earth Sci, 59, 1047-1055. https://doi.org/10.1007/s12665009-0096-3.

Tomlinson, C. J., Chapman, L., Trones, J. E., \& Baker, C. (2011). Remote sensingland surface temperature for meteorology and climatology: a review. Meteorol Appl, 18, 296-306. https://doi.org/10.1002/met.287.

Tucker, C. J. (1979). Red and photographic infrared linear combinations for monitoring vegetation. Remote Sens Environ, 8(2), 127-150.

USGS: Science for a Changing World. EarthExplorer. Retrieved from https://www.earthexplorer.usgs.gov

Voogt, J. A., \& Oke, T. R. (2003). Thermal Remote Sensing of Urban Climates. Remote Sens Environ, 86, 370-384.

https://doi.org/10.1016/S0034-4257(03)00079-8. 
Wang, J., Qingming, Z., Guo, H., \& Jin, Z. (2016). Characterizing the spatial dynamics of land surface temperature-impervious surface fraction relationship. Int J Appl Earth Obs Geoinf, 45, Part-A, 55-65. https://doi.org/10.1016/j.jag.2015.11.006.

Wang, L., Lu, Y., \& Yao, Y. (2019). Comparison of three algorithms for the retrieval of land surface temperature from Landsat 8 images. Sensors, 19(22), 5049.

Wen, L., Peng, W., Yang, H., Wang, H., Dong, L., \& Shang, X. (2017). An analysis of land surface temperature (LST) and its influencing factors in summer in western Sichuan Plateau: A case study of Xichang City. Remote Sens Land Res, 29(2), 207-214. https://doi.org/10.6046/gtzyyg.2017.02.30.

Wukelic, G. E., Gibbons, D. E., Martucci, L. M., \& Foote, H. P. (1989). Radiometric calibration of Landsat Thematic Mapper thermal band. Remote Sens Environ, 28, 339-347.

Yang, J., \& Qiu, J. (1996). The empirical expressions of the relation between precipitable water and ground water vapor pressure for some areas in China. Sci Atmos Sinica, 20, 620-626.

Yao, R., Cao, J., Wang, L., Zhang, W., \& Wu, X. (2019). Urbanization effects on vegetation cover in major African cities during 2001-2017. Int J Appl Earth Obs, 75, 44-53. https://doi.org/10.1016/j.jag.2018.10.011.

Yao, R., Wang, L., Gui, X., Zheng, Y., Zhang, H., \& Huang, X. (2017). Urbanization Effects on Vegetation and Surface Urban Heat Islands in China's Yangtze River Basin. Remote Sens, 9(6), 540. https://doi.org/10.3390/rs9060540.

Yao, R., Wang, L., Huang, X., Chen, J., Li, J., \&Niu, Z. (2018). Less sensitive of urban surface to climate variability than rural in Northern China. Sci Total Environ, 628-629, 650-660. https://doi.org/10.1016/j.scitotenv.2018.02.087.

Yao, R., Wang, L., Huang, X., Chen, X., \& Liu, Z. (2019). Increased spatial heterogeneity in vegetation greenness due to vegetation greening in mainland China. Ecol Indic, 99, 240-250. https://doi.org/10.1016/j.ecolind.2018.12.039.

Yao, R., Wang, L., Huang, X., Niu, Z., Liu, F., \& Wang, Q. (2017). Temporal trends of surface urban heat islands and associated determinants in major Chinese cities. Sci Total Environ, 609, 742-754. https://doi.org/10.1016/j.scitotenv.2017.07.217.

Yao, R., Wang, L., Huang, X., Zhang, W., Li, J., \& Niu, Z. (2018). Interannual variations in surface urban heat island intensity and associated drivers in China. J Environ Manage, 222, 86-94. https://doi.org/10.1016/j.jenvman.2018.05.024.

Yuan, M., Wang, L., Lin, A., Liu, Z., \& Qu, S. (2020). Vegetation green up under the influence of daily minimum temperature and urbanization in the Yellow River Basin, China. Ecol Indic, 108, 105760. https://doi.org/10.1016/j.ecolind.2019.105760.

Yuan, X., Wang, W., Cui, J., Meng, F., Kurban, A., \& De Maeyer, P. (2017). Vegetation changes and land surface feedbacks drive shifts in local temperatures over Central Asia. Sci Rep, 7(1), 3287. https://doi.org/10.1038/s41598017034322.

Yue, W., Xu, J., Tan, W., \&Xu, L. (2007). The Relationship between Land Surface Temperature and NDVI with Remote Sensing. Application to Shanghai Landsat 7 ETM+ data. Int J Remote Sens, 28, 3205-3226.

https://doi.org/10.1080/01431160500306906.

Zanter, K. (2019). Landsat 8 (L8) Data Users Handbook. EROS, Sioux Falls, SD, USA.

\section{Editor: Fábio Duarte}

Received: Sep. $25^{\text {th }}, 2020$

Approved: Jun. $30^{\text {th }}, 2021$ 